\title{
College Major and Modern Racism: A Matter of Moral Hypocrisy?
}

\author{
David Bryan Oxendine \\ Department of Elementary Education, School of Education, University of North Carolina at \\ Pembroke \\ P. O. Box 1510, Pembroke, North Carolina, 28372, United States \\ Email: david.oxendine@uncp.edu Tel: 1-910-521-6324
}

Received: June 23, 2017 Accepted: July 23, 2017 Published: September 11, 2017

doi:10.5296/iss.v5i2.11439 URL: http://dx.doi.org/10.5296/iss.v5i2.11439

\begin{abstract}
Research has demonstrated a relationship between gender, race, and modern racism. Recent studies have revealed this relationship exists in college business majors as well as in the world of business. Moral hypocrisy appears as a possible explanation of why apparently normal moral individuals at times, do behave in a less than moral manner when their self-interests are threatened. This paper explores how self-interest often overpowers moral integrity.
\end{abstract}

Keywords: college major, business, modern racism, self-interest, moral hypocrisy 


\section{Introduction}

Decades of research have demonstrated a strong relationship between gender, race, prejudice and modern racism (Allport, 1954; Bakanic, 2009; Cokely, Tran, Hall-Clark, Chapman, Bessa, Finley, \& Martinez, 2010; Dovidio \& Gaertner, 1986; Helgeson, 2005; McConahay, 1986; Nelson, 2006: Neville, Lilly, Duran, Lee, \& Browne, 2000; Neville, Spanierman, \& Doan, 2006; Oxendine, 2016a, 2016b; Oxendine \& Nacoste, 2007; Ponterotto, Burkand, Rieger, Grieger, D’Onofrios, Dubusison, Heenehan, Millstein, Parisi, Rath, \& Sax, 1995). Business practices and business ethics having links with prejudice and discriminatory practices may derive from the relationships between gender and race creating a dilemma; how top appear moral while still serving their self-interest (Batson, Collins, \& Powell, 2006; Corvino, 2006; Hoogervorst, De Cremer, \& van Dijke, 2011; Naso, 2006, 2007; Oxendine, 2016a, 2016b). The question then becomes why people who maintain moral principles, frequently behave in a manner that strongly contrasts with those principles?

Questions of concern relating to moral hypocrisy, moral integrity, and self-interest behaviors in recent years have interested social psychologists (Abrams, Houston, Van de Vyver, \& Vasiljevic, 2015; Batson, Kobrynowicz, Dinnerstein, Kampf, \& Wilson, 1997; Batson \& Thompson, 2001; Batson, Thompson, \& Chen, 2002; Batson, Thompson, Seuferling, Whitney, \& Strongman, 1999; Batson et al., 2006; Corvino, 2006; Naso, 2006, 2007; Ratner \& Miller, 2001; Valdesolo \& DeSteno, 2007). According to DeCelles, DeRue, Margolis, and Ceranic (2012), self-interest related behavior is a product of one's moral identity. Moral identity is the degree of morality comprised in an individual's self-concept, which then is a function of the emphasis one gives to their own or others' needs. One of the most important questions of this research is why people with moral principles often do not act or behave morally. In many cases, prejudice and discrimination occur, often masked as moral hypocrisy, when the distribution of goods and services between in-groups and out-groups creates an environment resulting in a moral dilemma (Batson et al., 2006; Pratto, Sidanius, Stallworth, Malle, \& Bertram, 1994).

According to Pratto et al. (1994), the notion of political-economic conservatism plays a vital role strongly supporting capitalism as opposed to socialism. Essentially, this implies there will be those achieving and obtaining less compared to those who are more competitive who gain more. Previous research has shown strong correlations with social dominance orientation (SDO) (Akrami \& Ekehammar, 2006; Pratto et al, 1994; Snellman \& Ekehammar, 2005). Oxendine (2016b) found support for participants from a conservative political orientation to hold more prejudiced and modern racial attitudes and beliefs. The issues addressed by this paper explores the notion of moral hypocrisy as a link between college major and modern racism as found by Oxendine (2016a).

\section{College Major}

In academia, traditionally Science, Technology, Engineering, and Mathematics (STEM) programs are overrepresented by males and underrepresented by females (Berryman-Fink, 2006; Brinkman \& Rickard, 2009; Brinkman, Garcia, \& Rickard, 2011; Deemer, Smith, Carroll, \& Carpenter, 2014; Garcia-Retamero \& López- Zafra, 2006; Leppel, 2001; Levin, Van Laar, \& Sidnaius, 2003; Nadal, Davidoff, Davis, Wong, Marshall, \& McKenzie, 2015; 
Rice, Lopez, Richardson, \& Stinson, 2013). Additionally, business programs, until recently were overrepresented by White males. Oxendine (2016a) found business majors held higher levels of modern racial attitudes and beliefs than did either Arts and Sciences and School of Education participants. Furthermore, business majors suggested that racism no longer existed and was not a big issue today.

\section{Modem Racism}

Old fashioned racism was demonstrated by the pre-civil rights era attitudes toward Blacks and other minorities, for example when businesses may tell their hiring managers to "lighten up" their sales people by reducing the number of Black employees or where "Blacks should not be employed to any position where they would be seen by customers" (Brief et al., pp. 73-74). Additionally, other ethnic groups in the United States such as American Indian, Asian, Latino, Mexican, as well as Eastern European have historically been subject to Racism, prejudice, and discrimination.

Most social psychologists have suggested that prejudice and racism operate at distinct levels such as the individual, interpersonal, intergroup, and at the institutional levels (Augoustinos \& Reynolds, 2002; Jackson, 2011; Sniderman, Piazza, Tetlock, \& Kendrick, 1991). Scholars have used the terms prejudice and racism interchangeably. Stereotypes, prejudice, and discrimination occur for example toward the target group based on politics, race, or gender.

Stereotypes are exaggerated generalizations about groups which are cognitive. These generalizations are internalized and become emotional which is prejudice. Taking this cognitive generalization, which is now emotionalized lead people to a physical manifestation which is now discrimination. One of the difficulties of eliminating these negative attitudes toward groups is that the basic core stereotype frequently is based on real traits (Lee, 2005; Schaefer, 2012). A current example would be using American Indian (Note 1) images as mascots for professional athletic teams in the United States. These mascots derived their origin from a time in history when viewing American Indians as savages with tomahawks was the norm, which would not be completely incorrect perhaps in certain situations early in United States history.

The implications of modern racism are that of a more indirect and rationalized behavior toward Blacks and other minorities where one's negative attitudes and behaviors are cloaked with nonracial attitudes and behaviors to appear non-racist. According to McConahay (1986), "the principal tenets of modern racism are these: (1) Discrimination is a thing of the past because Blacks now have the freedom to compete in the marketplace and to enjoy those things they can afford. (2) Blacks are pushing too hard, too fast, and into places where they are not wanted. (3) These tactics and demands are unfair. (4) Therefore, recent gains are underserved, and the prestige-granting institutions of society are giving Blacks more attention and the concomitant status than they deserve" (pp. 92-93). The individual with modern racial attitudes views themselves as non-racists because they view the first four tenets as non-racist because they are empirical facts and they recognize racism as inherently bad (Brief et al., 2000).

Oxendine (2004) found that individuals or groups that feel threatened by some form of social exclusion or devaluation over periods of time, cultures, and ethnic groups or gender become 
so deeply rooted these groups expect this type of treatment. Evolutionary psychologists suggest that natural selection over time has shaped the way these groups think, feel, or even how to behave (Jackson, 2011). Ethnocentricity is a phenomenon where one group genuinely behave and act that their in-group are superior to other groups. Historically, Whites have viewed themselves as non-raced which is demonstrated by the absence of color or raced speech in everyday language referring to themselves (Rothenberg, 2008). Until recently White group members may refer to others as the "Blackness" of Blacks, the "Chineseness" of Chinese, or the "Indianness" of American Indians. How often each day does the White population think about their whiteness, in contrast to Blacks, Asians, or American Indians? Minorities are aware of their "colorness" daily. For Whites, this is the advantage or privilege of being White. Without question, the social views in the United States have indeed evolved to be more inclusive regarding minorities and underrepresented groups. It would be reckless and inaccurate to proclaim racism is a social problem that no longer exists. After the presidential election of Barrack Obama in 2008, this rhetoric was repeatedly heard. Perhaps this was being heard because Americans wanted this to be true. A nation cannot reverse hundreds of years of attitudes and beliefs by a single political election.

Therefore, individuals with modern racial attitudes and beliefs do not view themselves as racists because they rationalize a racist as someone with the more blatant or holding to more old-fashioned or historical racial attitudes. McConahay (1986) found multiple factors that correlate with modern racial attitudes including, Protestant ethic conservatism, and demographics such as age, education, gender, and political orientation.

Additionally, self-interest theory plays a significant role in modern racist attitudes and beliefs concerning government policies of affirmative action. According to Oh, Choi, Neville, Anderson, and Landrum-Brown (2010), some issues arise when understanding why some oppose and others support efforts to promote diversity by affirmative action. Depending on which side of the spectrum one finds themselves, determines the role self-interest plays concerning one's support of such policies (Crandall, 1994; Kish-Gephart et al., 2014; Jackman, 1996; Ratner \& Miller, 2001).

\section{Moral Hypocrisy}

Social psychologists have defined moral hypocrisy as displaying behavior to the world as moral, but behaving in ways opposite of one who would be considered moral (Abrams et al., 2015; Batson et al., 1997; Batson et al., 1999; Batson \& Thompson, 2001; Batson et al., 2002; Batson et al., 2006; Corvino, 2006; Graham, Meindl, Koleva, Iyer, \& Johnson, 2015; Naso, 2006, 2007; Ratner \& Miller, 2001; Valdesolo \& DeSteno, 2007). According to Batson et al. (1999), moral hypocrisy is "a motive to appear moral in one's own and other's eyes, while, if possible, avoiding the cost of actually being moral" (p. 525). Batson et al. (1997) differentiated moral hypocrisy from moral integrity as the desire for one to behave morally. For many reasons, including social comparison, people are motivated to appear moral in order receive the benefits of such behavior, while in actuality they are motivated by their self-interests (Hoogervorst et al., 2011; Jackman, 1996; Kish-Gephart, Detert, Trevino, Baker, \& Martin, 2014; Oh et al., 2010).

History has shown that heinous deeds have been committed not only by villainous monsters, but also very horrendous acts have been perpetrated by normally, sincerely moral individuals. 
In recent decades, the world has witnessed "the endless procession of religious wars, mass killings, ethnic cleansings, terrorist bombings, and corporate cover-ups of product dangers" (Batson \& Thompson, 2001, p. 54). The question then becomes, how is this possible? Numerous studies suggest this issue viewed through a developmental psychological lens provides a clearer understanding, whereby a lack of moral nurturing and training occurred. Other studies suggest a social-environmental pressure perspective provides a better understanding. Directives by a person of authority, as demonstrated in the Milgram studies and pressure as in Asch's conformity studies (as cited in Batson \& Thompson, 2001) have been utilized to explain this phenomenon. These explanations only explain the issue partially, because people with average upbringing with a normal moral compass and those in less stressful environments have at times engaged in less than nominal moral behavior.

Social psychologists have shown theories of self-interest as a very powerful factor of human motivation for continued success and growth in areas such as big business. Examples of big business self-interest without restraint would be the 2008 financial recession and recent banking and business scandals (Abrams et al., 2015; Corvino, 2006; Hoogervorst et al., 2011; Jackman, 1996; Kish-Gephart et al., 2014). Another area of motivation according to Hoogervorst et al. is leader accountability. Leaders would be more motivated to appear accountable in the event they are required to justify their actions and decisions, without so could lead to charges of unethical behavior which would be counterproductive to their self-interests. In the event, leaders do not expect the need to justify their actions and decisions, could lead them to behave in ways that directly benefit their self-interests and not the interests of the public.

According to Naso (2006), moral hypocrisy is comprised of three components: integrity, antihypocrisy, and antisocial personality. Hypocrisy is at odds with integrity. A person of integrity welcomes diverse ideas and beliefs, values and prosocial behaviors. Integrity affords those with it the tools to avoid corruption by allowing their value system to maintain for them the resistance needed to constantly adjust and adapt to various circumstances and challenges that life brings their way. A renegotiation to one's integrity could occur when an individual perceives the successes of others as unfair, may feel vindicated by behaving opposite to their moral standard (Batson et al., 1997; Naso, 2006, 2007; Ratner \& Miller, 2001). It essentially becomes a "tug of war" between one's morality and self-interests, often leading to the latter winning.

A person of antihypocrisy also avoids corruption by an intolerance of moral uncertainty. These individuals adhere at all costs by high moral standards as motivation. The hypocrite, on the other hand, may operate by way of deception and the pursuit of self-interest as opposed to the interests of others (Batson et al., 1997; Naso, 2006, 2007; Ratner \& Miller, 2001). Therefore, the antihypocrite's moral standards are secure and stable and not subject to corruptibility. It is this incorruptibility which is absent in the antisocial behavioral individual. These individuals exploit moral standards for their self-interests often lead to under handing and criminal activity.

Valdesolo and DeSteno (2007) replicated, with minor changes, a paradigm by Batson et al., (1997), whereby, in one condition participants must distribute some resource to themselves and another either with equal fairness, or they could distribute the better resource to 
themselves (unfair). After which they were asked to evaluate the fairness of their actions. In another condition, participants observed and evaluated a confederate behaving in the same unfair manner. They defined moral hypocrisy as the difference between the fairness evaluations of the same behavior they enacted compared to those of others. Their findings confirmed a bias in moral reasoning; individuals perceive their behavior unfair, less intolerable than the same behavior enacted by others. According to Batson et al., moral motivation is to appear moral without the costs of being moral and still being able to serve self-interest. These findings suggest the actor is aware of the unfairness of their actions, but the drive to serve their self-interests is the worth the risk of being unmasked as behaving immorally.

According to Batson and Thompson (2001), most people have good intentions and therefore have moral integrity. Their studies have shown that participants view a coin toss as means to fairly assign resources. When the coin toss is not favorable to them, their moral integrity may cost them a positive outcome and negative consequences. Therefore the conflict occurs. It is at this point most often their self-interest overcomes their moral integrity and their motivation to appear moral is at a greater cost and self-interest often wins. This cost-based justification according to Batson and Thompson, explains why individuals set aside their moral principles to avoid the personal cost of negative consequences but also creates its set of negative implications. These findings are consistent with decades of research on cognitive dissonance by Festinger (as cited in Naso, 2006), whereby, when confronted with a dilemma between self-interest and their moral standard, rather than changing their behavior they reinterpret their self-interest as moral. Imagine the amount of negative cost required from self-interest for one to set aside their moral integrity, whereby, one stands by as innocent people are harmed, where no one intervenes while hate crimes occur, or no one strives to provide health care for the elderly, so a choice no longer exists between food, medicines, or paying the rent?

\section{Why Business?}

Second only to the political world regarding power leading to corruption would be the business world. The million dollar question is, does the business world make people corrupt or does the business profession attract the easily corruptible? According to Woodruff (2013), the answer is a very strong yes...maybe. Studies conducted at the University of Utah and Harvard University found that when participants exposed to the concept of money their thinking became impacted, triggering a business mind set thereby encouraging them to pursue their self-interests instead of thinking and behaving more in cooperation with others. Research in organizational behavior, organizational deviance, prosocial behavior, and moral behavior all support these findings (DeCelles et al., 2012).

Why do business majors and business people specifically, and business in general, often appear to hold greater levels of modern racial attitudes and beliefs? First, one must understand the mechanics of business. Essentially, business is about the business of the distribution of goods and services which are of some value. Individuals and groups, do not necessarily share the same values and have the same resources which create an environment of wheeling and dealing to satisfy each of our desires and needs (Batson et al., 1997; Jackman, 1996; Ratner \& Miller, 2001).

Somewhere along the line, we discover that with some slight adjustments, better exchanging 
of goods and services can be garnered which benefit ourselves without appearing to slight the other party. At that moment, parties gain knowledge and begin developing strategies to mislead and deceive the other for their self-interest and benefit. At the same time, the competition could attempt to mislead and deceive your interests to benefit their interests as well. Thus, begin the strategies for parties engaged in business exchanges to appear morally honest, sincere, and straightforward with their information to ensure their self-interested gains without being so.

Social exchange theory suggests that most of what we do in relationships are rooted in our desire to maximize our rewards while minimizing our costs (Kelley \& Thibaut, 1978; Thibaut $\&$ Kelley, 1959). Social exchange theorists view business ventures a group attempting to maximize their monetary interests while minimizing their monetary losses. An example of this according to Batson et al., 2006 was when big tobacco giant Philip Morris spent millions of dollars making known how philanthropic the company was by their great benevolent contributions to many charities. In so doing, this creates the appearance of high moral standards without truly being so. In many ways, this is of greater value, because if people trust you to be fair and honest, they will work with you while, you are not, that places one in a greater position to take advantage of the situation.

Additionally, according to social exchange theory, people's opinions about a relationship may depend on their perceptions or beliefs of the rewards they may receive, the possible costs of the relationship, how deserving they are of such relationships, or the likelihood they may find a more beneficial relationship (Aronson, Wilson, Akert, \& Sommers, 2016; Kelley \& Thibaut, 1978; Thibaut \& Kelley, 1959). In other words, we opt for the relationship that provides the most value, the least cost for the options available at the time. Satisfaction of the relationship depends on one's comparison level or the expectation of the outcome of the relationship based on its costs and rewards. According to Aronson et al., "reward, cost, outcome, and comparison level" (p. 332) are the basic tenets of social exchange theory, and one of the driving components of business relationships. The benefits of moral hypocrisy are clear: psychologically an individual or group can obtain the rewards and spoils from unfair and self-serving actions and behaviors and at the same time bask in the glow of social acceptance of appearing moral, fair, and honest.

\section{Conclusion}

Research has established a relationship between gender, race, prejudice and modern racism. This research extended further, establishes a similar relationship between college business majors, generally, and the business world specifically. Moral hypocrisy as a means of an explanation for this relationship was proposed. What can be deduced from this discussion? Can it be concluded that the world is composed mainly of moral hypocrites, or are there more subtle inferences? Self-interest is a normal human trait, therefore, if the moral hypocrite is seeking to satisfy their desires, does this mean we all must be moral hypocrites? Moral hypocrites seek to satisfy their desires above those of others while appearing to be moral perhaps because of the phenomenon known as "what others think" (Naso, 2007, p.114). These individuals strive above all to maintain this successful con showing little concern for those whom advantage has been taken.

Social psychologists suggest that most people initially intend to behave morally, but if 
circumstances or events stack up against them and their self-interests in a negative way, this conflict may create a moral dilemma, and they may act in a less than moral manner (Batson et al., 2006; Batson et al., 1997; Batson \& Thompson, 2001; Batson et al., 2002; Batson et al., 1999; Hoogervorst et al., 2011; Jackman, 1996; Naso, 2006, 2007; Wang \& Sun, 2015). Abundant research has established that it is common in general and specifically more common in the business world for individuals to exhibit the ability to hold certain moral beliefs and at the same time behave in a manner that completely contradicts the original held moral belief. The basic components of moral hypocrisy are integrity, antihypocrisy, and antisocial personality, according to Naso $(2006,2007)$. In other words, moral reasoning at the individual and group level moral hypocrisy appears to be context-dependent. Bias in moral reasoning occurs when individuals perceive identical behaviors in others more harshly than their own (Valdesolo \& De Steno, 2007). The reader should American Indian that moral hypocrisy is not limited to academic business majors or the business world exclusively, but occurs at all levels of public and private life including, but not limited to politics and individual personal relationships.

Further research is indicated for a clearer understanding of moral hypocrisy to implement new strategies to improve moral behavior while attaining corporate success. Corvino (2006) coined a phrase "morality pays" to the question "why be moral?" and recommended several steps that may lead to a better realignment of moral behavior and business success. These include, but are not limited to 1. Corporate policy, 2. Professional codes, 3. Criminal law, 4. Civil law, 5. Social pressure, 6. Media exposure, and 7. Character education. (p. 11). These recommendations are by no means a quick solution to this dilemma, but only a beginning point. Our relationships, whether personal or professional, can benefit from a better understanding of moral motivation in relationships. Self-interest, in and of itself is not evil, but left without some restraint may lead individuals and societies to a greater, morally corrupt world.

\section{Acknowledgement}

Dr. David B. Oxendine, Associate Professor, Department of Elementary Education, School of Education, University of North Carolina at Pembroke. Correspondence concerning this article should be addressed to Dr. David B. Oxendine, Department of Professional Pedagogy and Research at the University of North Carolina at Pembroke, P.O. Box 1510, Pembroke, N. C. 28372. E-mail: david.oxendine @ uncp.edu.

\section{References}

Abrams, D., Houston, D. M., Van de Vyver, J., \& Vasiljevic, M. (2015). Equality hypocrisy, inconsistency, and prejudice: The unequal application of the universal human right to equality. Peace and Conflict: Journal of Peace Psychology, 21(1), 28-46. http://dx.doi.org /10.1037/pac0000084

Akrami, A. \& Ekehammar, B. (2006). Right-wing authoritarianism and social dominance Orientation. Their roots in big-five personality factors and facets. Journal of Individual Differences, 27(3), 117-126. https://doi.org/10.1027/1614-0001.27.3.117

Alport, G. W. (1954). The nature of prejudice. Reading, MA: Addison-Wesley.

Aronson, E., Wilson, T. D., Akert, R. M., \& Sommers, S. R. (2016). Social psychology (9th 
ed.). Boston: Pearson.

Augoustinos, M. \& Reynolds, K. J. (2002). Prejudice, racism, and social psychology. In M. Augoustinos \& K. J. Reynolds (Eds.), Understanding prejudice, and social conflict (pp. 1-23). London: Sage Publications.

Bakanic, V. (2009). Prejudice: Attitudes about race, class, and gender. New Jersey: Pearson.

Batson, C. D. \& Thompson, E. R. (2001). Why don't moral people act morally? Motivational considerations. Current Directions in Psychological Science, 10(2), 54-57. http://o-dx.doi.org. bravecat.uncp.edu/10.1111/1467.8721.00114

Batson, C. D., Collins, E., \& Powell, A. A. (2006). Doing business after the fall: The virtue of moral hypocrisy. Journal of Business Ethics, 66, 321-335. https://doi.org/10.1007/s10551 -006-0011-8

Batson, C. D., Kobrynowicz, D., Dinnerstein, J. L., Kampf, H. C., \& Wilson, A. D. (1997). In a very different voice: Unmasking moral hypocrisy. Journal of Personality and Social Psychology, 72(6), 1335-1348. https://doi.org/10.1037/0022-3514.72.6.1335

Batson, C. D., Thompson, E. R., \& Chen, H. (2002). Moral hypocrisy: Addressing some alternatives. Journal of Personality and Social Psychology, 83(2), 330-339. https://doi.org/ 10.1037//0022-3514.83.2.330

Batson, C. D., Thompson, E. R., Seuferling, G., Whitney, H., \& Strongman, J. A. (1999). Moral hypocrisy: Appearing moral to oneself without being so. Journal of Personality and Social Psychology, 77(3), 525-537. https://doi.org/10.1037/0022-3514.77.3.525

Berryman-Fink, C. (2006). Reducing prejudice on campus: The role of intergroup contact in diversity education. College Student Journal, 40(3), 511-516.

Brief, A. P., Dietz, J., Cohen, R. R., Pugh, S. D., \& Vaslow, J. B. (2000). Just doing business: Modern racism and obedience to authority as explanations for employment discrimination. Organizational Behavior and Human Decision Processes, 81, 72-97. https://doi.org/10.1006 /obhd.1999.2867

Cokely, K. O., Tran, K., Hall-Clark, B., Chapman, C., Bessa, L., Finley, A., \& Martinez, M. (2010). Predicting student attitudes about racial diversity and gender equity. https://doi.org /10.37/a0020467

Corvino, J. (2006). Reframing "morality pays": Toward a better answer to "why be moral?" in business. Journal of Business Ethics, 87, 1-14. doi: 10.1007/s10551-006-9001-0

Crandall, C. S. (1994). Prejudice against fat people: Ideology and self-interest. Journal of Personality and Social Psychology, 66(5), 882-894. https://doi.org/10.1037/0022 $-3514.66 .5 .882$

DeCelles, K. A., DeRue, D. S., Margolis, J. D., \& Ceranic, T. L. (2012). Does power corrupt or enable? When and why power facilitates self-interested behavior. Journal of Applied Psychology, 97(3), 681-689. doi: 10.1037/a0026811

Dovidio, J. F. \& Gaertner, S. L. (1986). Prejudice, discrimination, and racism: Historical trends and contemporary approaches. In J. F. Dovidio \& S. L. Gaertner (Eds.), Prejudice, discrimination, and racism (pp. 1-34). New York: Academic Press. 
Graham, J., Meindl, P., Koleva, S., Lyer, R., \& Johnson, K. M. (2015). When values and behavior conflict: Moral pluralism and intrapersonal moral hypocrisy. Social and Personality Psychology Compass, 9(3), 158-170. https://doi.org/10.1111/spc3.12158

Helgeson, V. S. (2005). Psychology of gender (2nd ed.). New Jersey: Pearson.

Hoogervorst, N., De Cremer, D., \& van Dijke, M. (2011). Why leaders not always disapprove of unethical follower behavior: It depends on the leader's self-interest and accountability. Journal of Business Ethics, 95, 29-41. https://doi.org/10.1007/s10551 -011-0793-1

Jackman, M. R. (1996). Individualism, self-interest, and White racism. Social Science Quarterly, 77(4), 760-767.

Jackson, L. M. (2011). The psychology of prejudice: From attitudes to social action. Washington, D. C.: American Psychological Association.

Journal of Diversity in Higher Education, 3(3), 187-199. https//doi.org/10.37/a0020467

Kelley, H. H., \& Thibaut, J. W. (1978). Interpersonal relations: A theory of interdependence. New York, N. Y. Wiley.

Kish-Gephart, J., Detert, J., Trevino, L. K., Baker, V., \& Martin, S. (2014). Situational moral disengagement: Can the effects of self-interest be mitigated? Journal of Business Ethics, 125, 267-285. https://doi.org/10.1007/s10551-013-1909-6

Lee, R. M. (2005). Resilience against discrimination: Ethnic identity and other-group Orientation as protective factors for Korean Americans. Journal of Counseling Psychology, 52(1), 36-44. https://doi.org/10.1037/0022-0167.52.1.36lehman

Leppel, K. (2001). Race, Hispanic ethnicity, and the future of the college business major in the United States. Journal of Education for Business, 76(4), 209-215. http://dx.doi.org/10.108 0/08832320109601312

Levin, S., Van Laar, C., \& Sidanius, J. (2003). The effects of ingroup and outgroup friendships on ethnic attitudes in college: A longitudinal study. Group Processes \& Interg roup Relations, 6(1), 76-92. https://doi.org/10.1177/1368430203006001013

McConahay, J. B. (1986). Modern racism, ambivalence, and the Modern Racism Scale. In J. F. Dovidio \& S. L. Gaertner (Eds.), Prejudice, discrimination, and racism (pp. 61-89). Orlando, FL.: Academic Press.

Naso, R. C. (2006). Immoral actions in otherwise moral individuals: Interrogating the structure and meaning of moral hypocrisy. Psychoanalytic Psychology, 23(3), 475-489. https://doi.org/ 10.1037/0736-9735.23.3.475

Naso, R. C. (2007). Beneath the mask: Hypocrisy and the pathology of shame. Psychoanalytic Psychology, 24(1), 113-125. https//doi.org/10.1037/0736-9735.24.1.113

Nelson, T. D. (2006). The psychology of prejudice (2nd ed.). New York: Pearson.

Neville, H. A., Lilly, R. L., Duran, G. Lee, R. M, \& Browne, L. (2000). Construction and initial validation of the Color-Blind Racial Attitudes Scale (CoBRAS). Journal of Counseling Psychology, 47(1), 59-70. https://doi.org/10.1037/0022-0167.47.1.59

Neville, H. A., Spanierman, L., \& Doan, B. T. (2006). Exploring the association between color-blind racial ideology and multicultural counseling competencies. Cultural Diversity and Ethnic Minority Psychology, 12(2), 275-290. https://doi.org/10.1037/1099-9809.12.2.275 
Oh, E., Choi, C. C., Neville, H. A., Anderson, \& Landrum-Brown, J. (2010). Beliefs about affirmative action: A test of the group self-interest and racism beliefs models. Journal of Diversity in Higher Education, 3(3), 163-176. https://doi.org/10.1037/a0019799

Oxendine, D. (1995). Racial identity development among Lumbee American Indian college students on a predominately White campus. Unpublished master's thesis, North Carolina State University, Raleigh.

Oxendine, D. B. \& Nacoste, R. W. (2007). Who would claim to be that, who was not?: Evaluations of an ethnic validation procedure. Journal of Applied Social Psychology, 37(7), 1594-1629. https://doi.org/10.1111/j.1559-1816.2007.00229.x

Oxendine, D. B. (2004). The effects of social exclusion threat and justifications on perceived fairness of an ethnic validation procedure: Implications for Lumbee Federal Recognition. (Doctoral dissertation, North Carolina State University, 2004). Dissertation Abstracts International, (UMI No. 3154343).

Oxendine, D. B. (2016a). Gender, race, and college major: Do they predict modern racism? Journal of Social Science Studies, 3(2), 90-102. http://dx.doi.org/10.5296/jsss.v3i2.8835

Oxendine, D. B. (2016b). The relationship between political orientation and race on modern racism. Journal of Social Science Studies, 3(1), 67-82. http://dx.doi.org/10.5296 /jsss.v3il.7933

Ponterotto, J. G, Burkand, A., Rieger, B. P., Grieger, I., D’Onofrios, A., Dubusison, A., Heenehan, M., Millstein, B., Parisi, M., Rath, J. F., \& Sax, G. (1995, December). Development and initial validation of the Quick Discrimination Index (QDI). Educational and Psychological Measurement, 55(6), 1016-1031. https://doi.org/10.1177/001316449 5055006011

Pratto, F., Sidanius, J., Stallworth, L. M., \& Malle, B. F. (1994). Social dominance orientation: A personality variable predicting social and political attitudes. Journal of Personality and Social Psychology, 67(4), 741-763. https://doi.org/10.1037/0022 -3514.67.4.741

Ratner, R. K. \& Miller, D. T. (2001). The norm of self-interest and its effect on social action. Journal of Personality and Social Psychology, 81(1), 5-16. https://doi.org/10.1037 //0022-3514.81.1.5

Rothenberg, P. S. (2007). Race, class, and gender in the United States (7th ed.). New York: Worth Publishers.

Schaefer, R. T. (2012). Racial and ethnic groups (13th ed.). Boston: Pearson.

Sidanius, J., Pratto, F., \& Bobo, L. (1994). Social dominance orientation and the political psychology of gender: A case of invariance? Journal of Personality and Social Psychology, 67(6), 998-1011. https://doi.org/10.1037/0022-3514.67.6.998

Sidanius, J., Pratto, F., \& Bobo, L. (1996). Racism, conservatism, affirmative action, and intellectual sophistication: A matter of principled conservatism or group dominance? Journal of Personality and Social Psychology, 70(3), 476-490. https://doi.org/10.1037/0022 $-3514.70 .3 .476$

Snellman, A. \& Ekehammar, B. (2005). Ethnic hierarchies, ethnic prejudice, and social dominance orientation. Journal of Community \& Applied Social Psychology, 15, 83-94. 
https://doi.org/10.1002/casp.812

Sniderman, P. M., Piazza, T., Tetlock, P. E., \& Kendrick, A. (1991). The new racism. American Journal of Political Science, 35(2), 423-447. https://doi.org/10.2307/2111369

Thibaut, J. W., Kelley, H. H. (1959). The social psychology of groups. New York, N. Y. Wiley. Valdesolo, P. \& DeSteno, D (2007). Moral hypocrisy: Social groups and the flexibility of virtue. Psychological Science, 18(8), 689-690. https://doi.org/10.1111/j.1467-9280.200 7.01961.x

Wang, F. \& Sun, X. (2015). Absolute power leads to absolute corruption? Impact of power on corruption depending on the concepts of power one holds. European Journal of Social Psychology, 46, 77-89. https://doi.org/10.1002/ejsp.2134

Wilkins, D. E. (2002). American Indian politics and the American political system. New York: Rowman \& Littlefield.

Woodruff, M. (2013). The link between money and corruption is more insidious than we thought. Business Insider. Retrieved from http://www.businessinsider.com/how-likelypeople-are-to-be-corrupted-by-money-2013-6.

\section{Note}

Note 1. Throughout this paper the term American Indian is used to indicate indigenous peoples of North America. The term Native American is incorrect in that all peoples born on the North American continent could be considered Native American (Oxendine \& Nacoste, 2007; Wilkins, 2002). 